\title{
THE ASSOCIATION BETWEEN BODY MASS INDEX AND GENDER ROLE STRESS AMONG YOUNG HUNGARIAN MALES
}

\author{
(Received: 7 December 2018; accepted: 25 March 2019)
}

\begin{abstract}
According to literature references, Body Mass Index (BMI), the quality of sexual life, sexual activity, and satisfaction with sexual life are closely associated. However, we found no research dealing with the relation of gender role stress to the above-mentioned factors in our review of the literature. That is why we chose to focus our research on the association of BMI and gender role stress of young Hungarian adult men. Our data is from the 'Hungarostudy 2013' (SUSÁNSZKY \& SZÉKELY 2013) national representative survey $(\mathrm{N}=2000)$ of which 298 18-35-year-old men belonged to the subsample researched. Besides socio-demographic data, we used data on height, weight, selfrated health status, the WHO (World Health Organization) Well-Being Index, the Illness Intrusiveness Rating Scale and the short form of Beck Depression Inventory. The Male Gender Role Stress Scale (MGRS) was used to measure gender role stress.

Our results demonstrate that overweight and obesity play a significant role in the development of gender role stress. Young overweight and obese men in our sample were much more likely to report high gender role stress $(\mathrm{OR}=1.67)$ and within this, sexual performance related stress $(\mathrm{OR}$ $=1.76)$ and sexual arousal related stress $(\mathrm{OR}=3.15)$ than men with normal BMI.

As our research was aimed at investigating social expectations measurable in terms of gender role stress and not with real sexual dysfunctions per se, our results indicate that even male gender role expectations, more precisely, sexual performance related expectations, may cause considerable stress for overweight/obese men.
\end{abstract}

Keywords: male, gender role stress, Body Mass Index, obesity, overweight, sexual performance

\section{Introduction}

These days, overweight and obesity represent a major and growing issue worldwide. In developed countries, obesity is one of the leading risk factors of chronic illnesses (e.g. diabetes and impairments of the locomotive system) and a principal cause of death (e.g. cardiovascular diseases and malignant tumours) (WHO 2016). The findings

* Corresponding author: Anna Susánszky, Institute of Behavioural Sciences, Semmelweis University, Nagyvárad tér 4., H-1089 Budapest, Hungary; susanszky.anna@med.semmelweis-univ.hu. 
of the European Health Interview Survey (EHIS) revealed in 2014 that more than half of the adult Hungarian population (54\%) is overweight or obese. Both overweight and obesity are more frequent among men; 39 per cent of men are overweight and 21 per cent of men are obese, while such percentages are 28 per cent and 20 per cent for women, respectively (KSH 2015).

Overeating and physical inactivity are considered to be major factors in the development of obesity, and these items are strongly influenced by certain psychological factors. We can identify certain eating habits that are related to stress and stress-reducing methods in the background of obesity (FAITH et al. 1997). Several clinical studies have demonstrated the connection between chronic stress and obesity (Bose et al. 2009; De VRIENDT et al. 2009).

Emotional eating is a form of overeating. Eating is a response to negative emotions and stress in this case. This may explain weight gain and BMI increase. Numerous research studies have dealt with this topic. Results indicate that emotional eating is a mediator between depression and BMI. (VAN STRIEN et al. 2016a; 2016b; 2018). Depression and heightened stress usually lead to a decrease of appetite. However, in some cases, people report increased appetite in relation to stress and depression (in case of atypical depression). There are researchers who assume that this may be due to the dysregulation of eating. TAN and CHOW's (2014) research provides evidence that the dysregulation of eating acts as a mediator between stress and emotional eating.

Researchers increasingly emphasize the importance of complex investigation into the effects of stress. Distress can trigger negative physiological responses in the human body, such as cardiac arrhythmia, accelerated respiration, dysfunction of the digestive system, muscle spasms, perspiration, fatigue, and sleeping disorders. The continuous presence of stressors increases the probability of certain illnesses such as cardiovascular diseases (ROSENGREN et al. 2004). Life situations and events may become a source of stress if they are perceived as a threat by the individual. A person may experience a loss (e.g. death, divorce, loss of employment), an unmet (physiological or psychological) need, any damage to their self-esteem (e.g. a failure), and frustrated desires and aspirations as a threat. In addition, the research has also demonstrated that not only grave trauma and loss, but also everyday stress loads may increase the risk of illness and death (FALUS et al. 2010). Social expectations of compliance with gender roles may also appear as stressors in our everyday life (gender role stress). Scientific research was conducted to investigate the effects of female gender role stress first, because the changes in the female role model were more conspicuous than the changes in the male role model. The changed social position of women, however, has also caused changes in the position of men and the social expectations concerning the male gender role as well.

Several studies have been conducted to establish causality between female gender role stress and body image on the one hand, and eating disorders on the other (MARTZ et al. 1995; BEKKER \& Boselie 2002; MussAP 2007). Research findings have indicated that the incidence of eating disorders among women is associated with a higher-than-usual level of gender role stress. 
The effects of gender role stress on physical symptoms and sexuality (sexual functioning) among women have also been investigated (PERRY 2010).

Compared to women, research initially focused on studying the male body image and the various forms of male eating disorders at a later date, notwithstanding the fact that certain phenomena, such as muscle dysmorphia (previously called 'reverse anorexia'), were identified and analysed at a relatively early stage (POPE et al. 1993). Several Hungarian studies have also been conducted on the subject (BABUSA \& TÚRY 2012; BABUSA et al. 2012). As of today, researchers and therapists have described and presented certain issues that are expressly specific to men, such as exercise addiction (TERRY et al. 2004). While reviewing the literature, we have not encountered any discussion of the causal links between gender role stress and the aforementioned issues and dysfunctions.

There is a strong association between body mass index on the one hand, and the quality of sexual life, the level of sexual activity and satisfaction with sexual life on the other hand (KOLOTKIN et al. 2006). In 2006, within the framework of a French national survey of sexual behaviours, BAJOS and her fellow researchers (2010) investigated the relationship between body mass index and sexuality. Based on the results, they concluded that erectile dysfunction is significantly more common among overweight/obese men, but found no relation among other sexual dysfunctions (lack of sexual partner, frequency and duration of intercourse, satisfaction with sexual life) and body weight. The findings of this French research were later confirmed by EsPOSITO and her fellow researchers (2008), i.e. obese men have an approximately $30 \%$ higher risk of erectile dysfunction than normal weight subjects.

While conducting research into certain body weight issues, and having considered several psychological risk factors as well as demographic factors, researchers have found that, as a tendency, the weight of both sexes increases after marriage; overweight and obesity are more frequent both among married men and women (TÚRY \& SZABÓ 2000).

Our present study examines the associations of BMI and gender role stress among young Hungarian adult men. We hypothesised that overweight/obese men will experience more gender role stress, and, within this, higher levels of stress related to sexuality and sexual performance, than men characterised by normal BMI. Examining physical sexual problems was not among the aims of our research. The questionnaire was concerned only with anxiety having to do with these issues.

\section{Method}

\subsection{Sampling and Data Collection}

The data used in our research was collected during the nationwide representative survey 'Hungarostudy 2013' (HS-2013) (SUSÁNSZKY \& SzÉKELY 2013). The sample pool, consisting of 2000 individuals, proportionally represented the network of Hungarian municipalities; the number of sampling units was 145. As far as the principal 
socio-demographic indicators (sex, age, education, type of municipality) were concerned, the composition of the sample population was identical to the composition of the entire Hungarian population. The population that constituted the basis for such sample pool was the population of Hungarian nationals aged 18 or older, living in Hungary.

The PAPI method was used for data collection. Personal interviews were conducted for the main questionnaire. The gender role stress sub-questionnaire for 18-35 year old men $(\mathrm{N}=315)$ was self-administered, as it contained sensitive personal topics. Therefore, this method seemed to guarantee the most honest responses.

\section{Measures}

\subsection{Socio-demographic and Anthropometric Data}

Each participant completed the questions concerning their age, official marital status, partnership status, and their education; furthermore, they provided information regarding their height (in $\mathrm{cm}$ ) and weight (in $\mathrm{kg}$ ). We calculated the body mass index of the participants based on the latter two data sets. BMI was calculated as the ratio of self-reported weight to self-reported height squared; then, in accordance with the categories established by WHO, we divided the participants into four groups: underweight (BMI < 18.5), normal (BMI between 18.5 and 24.9), overweight (25.0-29.9) and obese $(\mathrm{BMI} \geq 30)$.

\subsection{The Masculine Gender Role Stress Scale (MGRS)}

The twelve-item short form of EISLER and SKIDMORE's (1987) Masculine Gender Role Stress Scale (MGRS) was used to measure gender role stress. (SUSÁNSZKY et al. 2004; SUSÁNSZKY et al. 2006). Data from a population survey (SUSÁNSZKY \& SZÁNTÓ 2004), in which the original, 40-item MGRS was completed by 212 men, was used for the shortening. The average age of the respondents was $39.0(\mathrm{SD}=15.4)$; the youngest person was 18 , the oldest was $86.14 \%$ of the respondents were university educated, $28 \%$ had secondary education, and $58 \%$ had elementary level education only ( 8 years of primary school and vocational training.)

In completing the test, respondents rated the listed scenarios based on how stressful they would be for them. (How stressful the situation would be for you, if. . .). A six-point Likert scale was used for evaluation. The bottom value was 'not stressful at all' and the top value was 'very stressful.' The authors separated five subscales from the original 40 items. In the shortening process, we chose the residual correlation descriptive of the two highest items $(0.580-0.838)$ per subscale as well as two items based on face validation. Hence, the original questionnaire was reduced to 12 items. Cronbach's alpha of the 40-item scale used on the Hungarian sample was 0.92 , while the Cronbach's alpha of the 12-item short form was 0.82 . The correlation value between the short and long form was 0.94 . The content of the subscales in the 
short form remained valid. We could form independent indicators from the items. Furthermore, the instrument became useable in epidemiological research, too.

\subsection{Indicators of health status}

Respondents rated their health status on a 5-point Likert scale (1-very bad, 2-bad, 3-average, 4-good, 5-excellent). We regarded this qualification as self-rated health status.

The 5-item version of the WHO Well-Being Index (WBI) was used to assess health related quality of life and provide information on how respondents felt in general. (BECH et al. 1996; SuSÁNSZKY \& SZÉKELY 2013). The 4-point scale was used to qualify statements regarding the last two weeks (not at all characteristic / hardly characteristic / characteristic / 100\% characteristic). The instrument does not contain reversed items. The greater scores mean the more positive, favourable mental states. Values from 0 to 15 points can be achieved on the scale.

The Illness Intrusiveness Rating Scale (DEvins 1994) is the other important indicator of health-related quality of life. This measures the extent to which illness and its treatment intrude on various areas of life. Out of the 13 items in the Hungarian version of this questionnaire (NovéK et al. 2005), the single item used in our research was the one asking about limitations in sexual life. Respondents could note the extent of limitation on a seven-point Likert scale. (1 - not very much, 7 - very much).

With regards to examining depression, the 9-item short form Beck's Depression Inventory (BDI) was used (BECK \& BECK 1972; KopP et al. 1990; RózSA et al. 2001). The instrument is based on the self-description of the respondents. The items of the instrument are social withdrawal, (indifference) indecisiveness, insomnia, fatigue, bodily preoccupation, work difficulties, self, self-accusation, pessimism and lack of ability to be satisfied or happy. The respondents registered their self-evaluation of each status indicator on a 4-point scale. Higher scores meant an increased prevalence of depression. The maximum score that could be achieved was 25 . A score of $0-9$ points means no syndromes of depression, 10-18 points indicates mild syndromes of depression, 19-25 points means moderate syndromes of depression while 25 points and above denotes severe syndromes of depression. The criteria of severe depression syndrome meet the clinical criteria of major depression.

\section{Statistical Analysis}

The data was analysed using the statistical package SPSS/PC, Version 22.0 (SPSS Inc., Chicago, Illinois, USA). We used Cronbach's alpha in order to assess the internal consistency of the MGRS questionnaire. We compared the various categories of gender role stress along the categories of BMI and partnership status using a chisquared test. By performing a binary logistic regression, we analysed the intensity and direction of the linear regression between the dichotomous dependent variable and the explanatory variables (categorical). The dependent variable was the stress 
load from gender roles $(1=$ high, $0=$ not high $)$ and the independent variables were the BMI $(0=$ normal, $1=$ overweight/obese $)$ and the relationship status $(0=$ lives alone, $1=$ lives in a relationship). During the evaluation of the results, we accepted $95 \%$ as significance level $(\mathrm{p}<0.05)$.

\section{Results}

As our research hypothesis concerned just those in the normal and above range (overweight/obese), only those 298 people, whose BMI value was at least 18.5 , were included in our subsample. We had the following BMI categories in the subsample: normal: 181 people $(60.9 \%)$, overweight: 86 people $(28.8 \%)$, obese: 31 people $(10.3 \%)$. Due to the low number of obese people in the sample, we used two BMI categories (normal and overweight/obese) in the analyses.

The average age of the subsample is 26.6 years $(\mathrm{SD}=5.4), 54.9 \%$ of the sample qualify as having low education (elementary school, vocational training), nearly a third has intermediate level education $(30.8 \%)$ and a tenth $(11.3 \%)$ has a university degree. The vast majority of the young men are unmarried $(81.3 \%)$, about one-fifth are married $(17.2 \%)$, and five people are divorced (1.5\%). Regarding relationship status, more than half of them live alone (58.7\%), the others cohabit with their partner $(41.3 \%)$.

We examined the proportion of those belonging to the high stress range in the 12-item MGRS scale as well as in the scale items dealing with sexuality and sexual performance by BMI category (Table 1). We considered people who ranked their stress level as 5 or 6 on the Likert scale items as belonging to the high-stress range, and in the case of the short form MGRS scale, those people whose average score value was 5 or higher.

Table 1

High level of gender role stress in normal and overweight/obese males

\begin{tabular}{|c|c|c|c|}
\hline \multirow{2}{*}{$\begin{array}{l}\qquad \text { MGRS Items } \\
\text { How stressful the situation would be for you, if. . . }\end{array}$} & \multicolumn{2}{|c|}{$\begin{array}{c}B M I \\
N(\%)\end{array}$} & \multirow[t]{2}{*}{$\begin{array}{c}\text { sig } \\
\mathrm{p}\end{array}$} \\
\hline & $\begin{array}{c}\text { Normal } \\
(18.5-24.9)\end{array}$ & $\begin{array}{l}\text { Overweight, } \\
\text { obese }(\geq 25)\end{array}$ & \\
\hline not able to find a sexual partner? & $66(36.5)$ & $55(47.4)$ & 0.061 \\
\hline unable to perform sexually? & $114(63.0)$ & $88(75.2)$ & 0.027 \\
\hline perceived as having feminine traits? & $110(60.8)$ & $85(70.9)$ & 0.073 \\
\hline unable to become sexually aroused when you want? & $99(54.7)$ & $92(80.2)$ & 0.000 \\
\hline MGRS scale & $85(47.0)$ & $70(60.3)$ & 0.024 \\
\hline
\end{tabular}


Based on Table 1, we can state that gender role stress (MGRS scale) and high sexuality related stress are associated with obesity and being overweight. The association was significant between sexual arousal $(\mathrm{p}=0.000)$, sexual performance $(\mathrm{p}=$ 0.027 ) and BMI categories. Tendency for association was manifest only in the case of high stress levels associated with establishing sexual relationships $(p=0.061)$ and appearing feminine $(\mathrm{p}=0.073)$. Obese and overweight men reported nearly one and a half times higher gender role stress (1.3) overall than those with normal body weight.

We went on to examine what other factors besides BMI play a direct or indirect role in shaping gender role stress and, within this, sexuality-related stress. Based on our literature review (see the introduction) the assumption was made that partnership status is associated with the BMI of men on one hand, and the development of their gender role stress level on the other. The proportion of overweight/obese men in our sample is bigger among those living in a relationship $(\mathrm{Chi}=5.783, \mathrm{df}=1, \mathrm{p}=0.016)$ than among single men $(33.3 \%)$.

Our second table contains the results of the association between partnership status and gender role stress (Table 2). Only sexual arousal showed significant association with relationship status. In this case high stress level was more significantly frequent among those living with their partner ( $71.5 \%$ vs. $59.8 \%)$.

Table 2

High level of gender role stress in partnership status

\begin{tabular}{|c|c|c|c|}
\hline \multirow{2}{*}{$\begin{array}{c}\qquad \text { MGRS Items } \\
\text { How stressful the situation would be for you, if. . . }\end{array}$} & \multicolumn{2}{|c|}{ Partnership status } & \multirow{2}{*}{$\begin{array}{l}\text { sig } \\
\mathrm{p}\end{array}$} \\
\hline & $\begin{array}{l}\text { single } \\
N(\%)\end{array}$ & $\begin{array}{c}\text { in relationship } \\
N(\%)\end{array}$ & \\
\hline not able to find a sexual partner? & $70(40.2)$ & $51(41.5)$ & 0.831 \\
\hline unable to perform sexually? & $116(66.3)$ & $86(70.5)$ & 0.445 \\
\hline perceived as having feminine traits? & $114(65.1)$ & $79(64.2)$ & 0.871 \\
\hline unable to become sexually aroused when you want? & $104(59.8)$ & $88(71.5)$ & 0.037 \\
\hline MGRS scale & $87(50.0)$ & $68(55.3)$ & 0.364 \\
\hline
\end{tabular}

Health status - as well as physical and emotional well-being - also influences the sense of gender role and sexuality-related stress. That is why we examined the association of our query variable with subjective health status, mood disorders typical of depression as well as disease burden.

The young men evaluated their health status rather favourably, and no significant deviation was found among the groups in any query variable. $85.8 \%$ of the 
respondents rated their health as good or excellent. The situation is similar in the case of health-related quality of life with groups rating around 11 points. Significant deviation in relation to sexual performance was observed only in the case of the point values of depression. Nevertheless, the average score (6.05 vs. 3.29) of both groups is normal, that is, it belonged to the 'no depressive syndromes' category (Table 3).

Table 3

Average scores of WHO and BDI by MGRS items

\begin{tabular}{|c|c|c|c|c|c|}
\hline MGRS & & WHO & $p$ & $B D I$ & $p$ \\
\hline \multirow{2}{*}{$\begin{array}{c}\text { - not being able to find a sexual } \\
\text { partner }\end{array}$} & low & $11.33(2.97)$ & 0.366 & $3.61(8.00)$ & 0.148 \\
\hline & high & $11.01(3.13)$ & & $5.14(10.12)$ & \\
\hline \multirow{3}{*}{ - being unable to perform sexually } & low & $10.09(3.17)$ & 0.242 & $6.05(11.24)$ & 0.017 \\
\hline & & & & & \\
\hline & high & $11.34(2.97)$ & & $3.39(7.53)$ & \\
\hline \multirow{2}{*}{$\begin{array}{c}\text { - being perceived as having feminine } \\
\text { traits }\end{array}$} & low & $10.95(2.98)$ & 0.297 & $5.26(10.61)$ & 0.150 \\
\hline & high & $11.34(3.06)$ & & $3.69(7.89)$ & \\
\hline \multirow{2}{*}{$\begin{array}{l}\text { - being unable to become sexually } \\
\text { aroused when you want }\end{array}$} & low & $11.31(2.96)$ & 0.636 & $4.97(10.91)$ & 0.302 \\
\hline & high & $11.14(3.08)$ & & $3.84(7.68)$ & \\
\hline & low & $11.26(2.96)$ & 0.736 & $4.77(9.88)$ & 0.312 \\
\hline \multicolumn{6}{|l|}{ Total MGRS scale } \\
\hline & high & $11.14(3.11)$ & & $3.73(8.00)$ & \\
\hline
\end{tabular}

None of the respondents mentioned having any illness or treatment that would limit their sexual life to any degree.

In summary, we may conclude that none of the above-mentioned variables proved to be a significant factor in shaping gender role stress or sexuality-related stress. We went on to use logistic regression analysis to see what kind of association there was between overweight, obesity and gender role stress and sexuality-related stress, given that we adjusted the data for relationship status. The results of the regression models are shown in Table 4. Every variable featured in the model is included in the table. The values of the Odds Ratios (Exp (B)) and their confidence intervals are also noted (95\% C.I. for $\operatorname{Exp}(\mathrm{B}))$.

As we see in the case of the models below, overweight and obese men are much more likely to report high levels of gender role stress $(\mathrm{OR}=1.67)$ - and within this, sexual arousal stress and sexual performance related stress - than men with normal body weight. 
Table 4

Regression models of high level of gender role stress

\begin{tabular}{|c|c|c|c|c|c|}
\hline & 1. model & 2. model & 3. model & 4. model & 5. model \\
\hline & $\begin{array}{l}\text { not being able } \\
\text { to find } \\
\text { a sexual partner }\end{array}$ & $\begin{array}{c}\text { being unable } \\
\text { to perform sexually }\end{array}$ & $\begin{array}{c}\text { being perceived } \\
\text { as having feminine } \\
\text { traits }\end{array}$ & $\begin{array}{c}\text { being unable } \\
\text { to become sexually } \\
\text { aroused } \\
\text { when you want }\end{array}$ & total MGRS scale \\
\hline & $\operatorname{Exp}(B) 95 \%$ C.I. & $\operatorname{Exp}(B) 95 \%$ C.I. & $\operatorname{Exp}(B) 95 \%$ C.I. & $\operatorname{Exp}(B) 95 \%$ C.I. & $\operatorname{Exp}(B) 95 \%$ C.I. \\
\hline$B M I(1)$ & $1.55(0.96-2.50)$ & $1.76(1.04-2.97)$ & $1.60(0.97-2.65)$ & $3.15(1.83-5.43)$ & $1.67(1.04-2.69)$ \\
\hline living together (I) & $0.98(0.61-1.58)$ & $1.11(0.07-1.86)$ & $0.91(0.56-1.48)$ & $1.49(0.89-2.50)$ & $1.16(0.73-1.86)$ \\
\hline Constants & 0.58 & 1.65 & 1.65 & 0.752 & 0.32 \\
\hline
\end{tabular}

\section{Discussion/Conclusions}

Our research examined the associations of gender role stress and Body Mass Index among young Hungarian men (18-35 year old). The proportion of overweight/obese men was $39.1 \%$ in our subsample. In accordance with literature reference, the proportion of obese and overweight men was much higher among those in a relationship than among single men.

As expected, we found that levels of gender role stress are higher among overweight and obese men than among men in the range of normal BMI. We found no evidence of the effect of different types of partnership status.

The results of the present study corroborate the results of our previous research (SUSÁNSZKY et al. 2013) The anxiety related to sexual performance, physical appearance, and providing support for one's family, generated by traditional expectations regarding gender roles, causes a significantly high level of stress among adult Hungarian males. This level is higher than any other anxiety caused by the changing gender roles in a modernising society. Modernised gender roles very seldom appear as stress factors; at the same time, failed adaptation to traditional role expectations significantly increases the respective stress load, and such increased stress levels are in very close connection with certain health-deteriorating practices, such as smoking (SUSÁNSZKY et al. 2009).

Within the framework of our previous research among adult males, our investigations were limited to the effects of traditional socio-demographic factors relating to gender role stress. Based on such results, we found that the level of gender role stress depends on the age, education, marital status, economic activity and ethnicity of the individual in question. We have introduced a new factor within the framework of our present research relative to the social representation of the human body, i.e. overweight and obesity; and - regarding the findings of our previous research concluding 
that gender role stress significantly decreases with age - we created our sample population from young males. The results of our research demonstrate that overweight and obesity play a significant role in gender role stress.

Due to the cross-sectional nature of our research, we could only study associations among the variables. Establishing causal relationships was not possible. Nevertheless, based on previous research reported in the literature, we can assume that gender role stress may increase the possibility and/or frequency of emotional eating, so higher body weight may denote higher stress levels. On the other hand, being overweight or obese is a source of stress in itself, as obesity and being overweight are held to be rather negative states in western culture. Today, there are numerous research studies to support that weight stigma and critical comments are not only ineffective in helping weight loss efforts, they actually hinder it. Weight stigma and discrimination are in fact sources of stress expressively leading to weight gain and poor health status (TOMIYAMA et al. 2018; MAJOR et al. 2018; CZEGLÉDI 2016).

\section{Limitations}

As our study was not aimed at researching actual sexual dysfunctions, we can only deduce that even assuming and thinking about sexual performance expectations can be problematic for overweight/obese men, causing them considerable stress.

Also, high BMI may indicate either a high level of muscle mass or a high level of body fat, and lower BMI may also indicate lean musculature. BMI does not tell us anything about the body composition. Which means that those who are considered as overweight/obese may have huge muscles. Having gender role stress as a bodybuilder or an obese man makes a huge difference.

\section{References}

BABUSA, B. \& F. TÚRY (2012) 'Muscle dysmorphia in Hungarian Non-Competitive Male Bodybuilders', Eating and Weight Disorders 17, 49-53.

Babusa, B., R. Urbán, E. CZeglédi \& F. TÚRY (2012) 'Psychometric Properties and Construct Validity of the Muscle Appearance Satisfaction Scale among Hungarian Men', Body Image 9, 155-62 (https://doi.org/10.1016/j.bodyim.2011.08.005).

Bajos, N., K. Wellings, C. Laborde \& C. Moreau (2010) 'Sexuality and Obesity, a Gender Perspective: Results from French National Random Probability Survey of Sexual Behaviours', British Medical Journal 340:c2573 (https://doi.org/10.1136/bmj.c2573).

Bech, P., K. Staehr-Johansen \& C. Gudex (1996) 'The WHO (Ten) Well-Being Index: Validation in Diabetes', Psychotherapy and Psychosomatics 65, 183-90 (https://doi.org/10.1159/ 000289073).

BECK, A.T. \& R.W. BeCK (1972) 'Shortened Version of BDI', Postgraduate Medicine 52, 81-85. BeKKer, M.H.J. \& K.A.H.M. Boselie. (2002) 'Gender and Stress: Is Gender Role Stress? A ReExamination of the Relationship between Feminine Gender Role Stress and Eating Disorders', Stress and Health 18, 141-49 (https://doi.org/10.1002/smi.933). 
Bose, M., B. Oliván \& B. LAferrère (2009) 'Stress and Obesity: The Role of The Hypothalamic-Pituitary-Adrenal Axis in Metabolic Disease', Current Opinion in Endocrinology, Diabetes and Obesity 16, 340-46 (https://doi.org/10.1097/MED.0b013e32832fa137.)

CZEGLÉDI, E. (2016) ‘A stresszkezelés alkalmazási lehetőségei az elhízás kezelésében’ [Stress Management Techniques in the Treatment of Obesity] Orvosi Hetilap 157, 260-67 (https:// doi.org/10.1556/650.2016.30362).

De Vriendt, T., L.A. Moreno \& S. De Henauw (2009) 'Chronic Stress and Obesity in Adolescents: Scientific Evidence and Methodological Issues for Epidemiological Research', Nutrition, Metabolism and Cardiovascular Diseases 19, 511-19 (https://doi.org/10.1016/j. numecd.2009.02.009).

DEVINS G.M. (1994) 'Illness Intrusiveness and the Psychosocial Impact of Lifestyle Disruptions in Chronic Life-Threatening Disease' Advances in Renal Replacement Therapy 1, 251-63 (https://doi.org/10.1016/S1073-4449(12)80007-0).

EISLER, R.M. \& SKIDMORE J.R. (1987) 'Masculine Gender Role Stress (MGRS): Scale Development and Component Factors in the Appraisal of Stressful Situations', Behavior Modification 11, 123-36 (https://doi.org/10.1177/01454455870112001).

Esposito, K, F. Giugliano, M. Ciotola, M. De Sio, M. D’armiento \& D. Giugliano (2008) 'Obesity and Sexual Dysfunction, Male and Female' International Journal of Impotence Research 20, 358-65 (https://doi.org/10.1038/ijir.2008.9).

FAith, M.S., D.B. Allison \& A. GeliebTer (1997) 'Emotional Eating and Obesity: Theoretical Considerations and Practical Recommendations' in S. DAlton, ed., Overweight and Weight Management: The Health Professional's Guide to Understanding and Practice (Gaithersburg: Aspen) 439-65.

Falus, A., I. Marton, E. Borbényi, Á. TAhy, P. KarÁdi, J. Aradi, A. Stauder \& M. Kopp (2010) 'A 2009. évi orvosi Nobel-díj és egy meglepő üzenete: az életmód befolyásolja a telomerázaktivitást' [2009 Nobel Prize in Medicine and an Interesting Message: Telomerase Activity is Associated with Lifestyle'] Orvosi Hetilap 151(24) 965-70 (https://doi.org/10.1556/ OH.2010.28899).

KOPP, M., Á. SKRABSKI \& L. CZAKÓ (1990) ‘Összehasonlító mentálhigiénés vizsgálatokhoz ajánlott módszertan' [Methodology Recommended for Comparative Mental Health Research] Végeken 1 (2) 4-24.

Kolotkin, R.L., M. Binks, R.D. Crosby, T. Østbye, R.E. Gress \& T.D. Adams (2006) 'Obesity and Sexual Quality of Life', Obesity 14(3) 472-79 (https://doi.org/10.1038/oby.2006.62)

KSH (2015) 'Európai lakossági egészségfelmérés, 2014' [European Population Health Survey 2014] Statisztikai Tükör 29, 1-9, retrieved 29 April 2019 from https://www.ksh.hu/docs/hun/ xftp/stattukor/elef14.pdf.

Major, B., A.J. TOMiYAma \& J.M. Hunger (2018) 'The Negative and Bidirectional Effects of Weight Stigma on Health' in B. MAJOR., J.F. DAvidio \& B.G. Link, eds., The Oxford Handbook of Stigma, Discrimination and Health (New York, NY: Oxford UP) 499-519.

MarTZ, D.M., K.B. HANDleY \& R.M. EisLeR (1995) 'The Relationship between Feminine Gender Role Stress, Body Image, and Eating Disorders', Psychology of Women Quarterly 19, 493 508 (http://dx.doi.org/10.1111/j.1471-6402.1995.tb00088.x).

MussaP, A.J. (2007) 'The Relationship between Feminine Gender Role Stress and Disordered Eating Symptomatology in Women.' Stress and Health 23, 343-48 (https://doi.org/10.1002/ smi.1152).

Novák, M., K. Mah, M.Zs. Molnar, Cs. Ambrus, G. Csepanyi, A. Kovacs, E. Vamos, M. Zambo, R. Zoller, I. Mucsi \& G.M. Devins (2005) 'Factor Structure and Reliability of the Hungarian Version of the Illness Intrusiveness Scale: Invariance across North American and 
Hungarian Dialysis Patients', Journal of Psychosomatic Research 58, 103-10 (https:// doi.org/10.1016/j.jpsychores.2004.05.008).

Perry, K.L. (2010) Gender Role and Women's Health: Effects of Feminine Gender Role Stress and Femininity on Somatic Symptoms and Sexual Functioning (PhD diss., Seattle Pacific University, Seattle).

Pope, H.G.J.R., D.L. Katz \& J.I. Hudson. (1993) "Anorexia Nervosa and "Reverse Anorexia" Among 108 Male Bodybuilders', Comprehensive Psychiatry 34, 406-9.

Rosengren A., S. Hawken, S. Ounpuu, K. Sliwa, M. Zubaid, W.A. Almahmeed, K.N. Blackett, C. Sitthi-Amorn, H. Sato \& S. Yusuf \& (2004) 'Association of Psychosocial Risk Factors with Risk of Acute Myocardial Infarction in 11119 Cases and 13648 Controls from 52 Countries (the INTERHEART Study): Case-Control Study', The Lancet 364, 953-62 (https://doi.org/10.1016/S0140-6736(04)17019-0).

RózSA, S., E. SzÁDÓCZKY \& J. FÜREDI (2001) ‘A Beck Depresszió Kérdöív rövidített változatának jellemzői hazai mintán' [Characteristics of the Short Form Beck Depression Inventory on a Hungarian Sample] Psychiatria Hungarica 16, 379-97.

SUSÁNSZKY, É. \& Zs. SZÁNTÓ (2004) 'A biotechnológia és az orvostudomány vívmányainak lakossági fogadtatása' [Lay reception of the achievement of biotechnology and medical science] Lege Artis Medicinae 14 (3) 220-5.

SusÁNSZKY, É. \& A. SzÉKELY (2013) 'A Hungarostudy 2013 felmérés módszertana' [The Methodology of the Hungarostury 2013 Survey] in in É. SusÁnSZKY \& Zs. SzÁNTÓ, eds., Magyar lelkiállapot [The Hungarian State of Mind] 13-21.

SusÁNSZKY, A., É. SUSÁNSZKY \& Zs. SZÁNTÓ (2004) 'The Influence of Gender-Role Stress on the Health of Males', International Congress of Behavioural Medicine (ICBM), Satellite Meeting, Budapest 2004. 08. 29-31., in: Programme and Abstract Book (Budapest: „János Selye” Hungarian Society of Behavioural Sciences and Medicine) 80-81.

SusÁNSZKY, A., É. SusÁNSZKY \& Zs. SzÁNTó (2006) 'The Influence of Gender-Role Stress on Males' Health', Psychology \& Health 21, Suppl. 1, 147 (https://doi.org/10.1080/1476832 0600901313).

SUSÁNSZKY, A., É. SUSÁNSZKY \& M. KoPP (2009) Mitől szoronganak a magyar férfiak? A magyar férfi szerep stresszjellegzetességei' [Why Are Hungarian Men Anxious? Stress Characteristics of the Hungarian Male Role] Lege Artis Medicinae 19 (6-7) 431-35.

SusÁnszKY, A., Sz. DukAY-SzabÓ, Zs. GYŐRFFY \& Sz. ÁdÁM (2013) 'Fiatalok házassággal és gyermekvállalással kapcsolatos beállítódása a férfi és női nemiszerep-stressz viszonylatában' [Attitudes towards Marriage and Child Bearing of Young People in Relation to Male and Female Gender Role Stress] in É. SUSÁNSZKY \& Zs. SzÁNTó, eds., Magyar lelkiállapot [The Hungarian State of Mind] 245-54.

TAN, C.C. \& C.M. ChOw (2014) 'Stress and Emotional Eating: The Mediating Role of Eating Dysregulation', Personality and Individual Differences 66, 1-4 (https://doi.org/10.1016/ j.paid.2014.02.033).

Terry, A., A. Szabo \& M.D. Griffiths (2004) 'The Exercise Addiction Inventory: A New Brief Screening Tool', Addiction Research and Theory 12. 489-99 (https://doi.org/10.1136/ bjsm.2004.017020).

Tomiyama, A.J., D. Carr, E.M. Granberg, B. Major, E. Robinson, A.R. Sutin \& A. Brewis (2018) 'How and Why Weight Stigma Drives the Obesity 'Epidemic' and Harms Health' BMC Medicine 16:123 (https://doi.org/10.1186/s12916-018-1116-5).

TÚRY, F. \& P. SZABÓ (2000) A táplálkozási magatartás zavarai: az anorexia nervosa és a bulimia nervosa [Nutritional Disorders: Anorexia Nervosa and Bulimia Nervosa] (Budapest: Medicina). 
van Strien, T., L. Winkens, M.B. Toft, S. Pedersen, I. Brouwer, M. Visser \& L. LÄhteenmäki (2016a) 'The Mediation Effect of Emotional Eating between Depression and Body Mass Index in the Two European Countries Denmark and Spain', Appetite 105, 500-8 (https://doi.org/10.1016/j.appet.2016.06.025).

van Strien, T., H. Konttinen, J.R. Homberg, R:C: Engels \& L.H. Winkens (2016b) 'Emotional Eating as a Mediator between Depression and Weight Gain', Appetite 100, 216-24 (https://doi.org/10.1016/j.appet.2016.02.034).

VAN STRIEN, T. (2018): 'Causes of Emotional Eating and Matched Treatment of Obesity', Current Diabetes Riports 18:35 (https://doi.org/10.1007/s11892-018-1000-x).

WHO (2016) Obesity and Overweight, retrieved 4 April 2017 from http://www.who.int/mediacentre/factsheets/fs311/en/. 